\title{
Mole per Gram
}

National Cancer Institute

\section{Source}

National Cancer Institute. Mole per Gram. NCI Thesaurus. Code C68893.

A unit of amount of substance content (molality unit) defined as one mole of solute per one gram of solvent. 